\title{
Nazwiska niemieckie z Reszla z XVI i XVII wieku na litery A i B
}

\author{
German names from Reszel \\ from the $16^{\text {th }}$ and $17^{\text {th }}$ c. starting with letters $A$ and $B$ \\ Marzena GUZ1 \\ Uniwersytet Warmińsko-Mazurski w Olsztynie
}

\begin{abstract}
Streszczenie
Celem artykułu jest przedstawienie pochodzenia nazwisk genetycznie niemieckich, wskazanie, czy mają swoje odmianki, co jest ich przyczyną, czy badane nazwiska wystąpiły jeszcze w XVIII na Warmii i w XX wieku w dawnym województwie olsztyńskim. Materiał badawczy pochodzi z Księgi Chrztów z Reszla o numerze E 462 = Rössel, Taufregister: MAI 1579-1653, która znajduje się w Archiwum Archidiecezji Warmińskiej w Olsztynie. Większość badanych mian stanowią nazwiska o jednej motywacji. Te nazwiska pochodzą głównie od nazw miejscowości, od nazw zawodów oraz imion. Odmianki (warianty) posiada 10 nazwisk. Najwięcej odmianek mają nazwiska Arend (4) i Berndt (5). Przyczynami występowania odmianek badanych nazwisk są $\mathrm{m}$. in.: wymiana $d \rightarrow d t \rightarrow t$, $s \rightarrow \mathcal{B}$, polonizacja nazwisk, podwajanie samogłosek i spółgłosek bez uzasadnienia, uproszczenie grupy spółgłoskowej, wymiana dyftongów. Do XVIII wieku nie przetrwało $10 \mathrm{z}$ badanych nazwisk, zaś w XX wieku pojawiło się ich tylko dziewięć.

Słowa kluczowe: nazwiska, etymologia nazwisk, warianty nazwisk, Warmia, Reszel, XVI i XVII w.

\section{Abstract}

This paper aims to present the origin of German surnames to indicate whether they have variants, their origin, and whether the surnames under investigation could still be found in Warmia in the $18^{\text {th }}$ century and the $20^{\text {th }}$ century in the former province of Olsztyn.
\end{abstract}

1 (D) https://orcid.org/0000-0003-4630-2584

Uniwersytet Warmińsko-Mazurski w Olsztynie

marzgu@op.pl 
The research material comes from the Reszel Baptismal Register Number E $462=$ Rössel, Taufregister: MAI 1579-1653, kept in the Archive of the Warmian Archdiocese in Olsztyn. The majority of the examined appellations are names with a single motivation. These surnames are mainly derived from place names, from names of professions and from first names. Ten surnames have variants (alternatives). The surnames Arend (4) and Berndt (5) have the largest number of alternatives. The reasons for the occurrence of variants of the examined surnames include: $d \rightarrow d t \rightarrow t, s \rightarrow B$ change, Polonisation of surnames, doubling of vowels and consonants without justification, simplification of the consonant group, and the change of diphthongs. Ten of the examined surnames had ceased to exist by the $18^{\text {th }}$ century, while only nine were found in the $20^{\text {th }}$ century.

Keywords: surnames, etymology of surnames, variants of surnames, Warmia, Reszel, $16^{\text {th }}$ and $17^{\text {th }}$ centuries

\section{Wprowadzenie}

Miasto Reszel leży na Warmii w województwie warmińsko-mazurskim, w powiecie kętrzyńskim. Liczy mniej niż 5000 mieszkańców. Prawa miejskie uzyskało w 1337 roku. Kolonizacja ziem Warmii rozpoczęła się wkrótce po zajęciu ich przez Zakon Krzyżacki. Około połowy XIV wieku ustał znaczny napływ osadników z Niemiec, co spowodowane było wybuchem wielkiej zarazy w Niemczech (Siatkowski, 1967, s. 112). Jedynie ludność niemiecka z okolic Elbląga przemieściła się do wschodniej części Warmii. Powstało wtedy miasto Reszel, zaludniły się jego okolice, aż do Bisztynka, przywędrował z nimi też dialekt dolnoniemiecki (Tolksdorf, 1991, s. 540; Żebrowska, 1998, s. 452).

Celem artykułu jest przedstawienie pochodzenia nazwisk genetycznie niemieckich, wskazanie, czy mają swoje odmianki, co jest ich przyczyną, czy badane nazwiska wystąpiły jeszcze w XVIII na Warmii i w XX wieku w dawnym województwie olsztyńskim.

A. Cieślikowa (2008, s. 32) przytacza następujące przyczyny odrębności graficznej nazwisk (występowania odmianek nazwisk):

- Nazwiska powstawały w czasie, kiedy nie obowiązywały reguły ortograficzne.

- Nazwiska wywodzą się głównie z języka mówionego.

- Nazwiska zapisywane były przez urzędników i księży różnych narodowości.

- Postać nazwiska uzależniona była od geografii i chronologii, ponadto od zwyczajów graficznych charakterystycznych dla danego okresu oraz zlokalizowania geograficznego gwary. 
- Bywały przypadki, że grafię nazwiska ustalał nosiciel lub jego otoczenie, by nazwisko różniło się od wyrazu pospolitego.

- Wpływ na formę nazwiska miały też nazwiska obce, które czasem stanowiły wzór, czasem były adaptowane przez zapisujących.

Kolejnym czynnikiem było przekręcenie nazwy miejscowej (Zoder, 1968 I, s. 132) lub jej archaiczny zapis, np. Cölln (dziś: Köln (pol. Kolonia) (por. Hartig, 1996, s. 1259).

Materiał badawczy pochodzi z Księgi Chrztów z Reszla o numerze E 462 = Rössel, Taufregister: MAI 1579-1653, która znajduje się w Archiwum Archidiecezji Warmińskiej w Olsztynie.

Nazwiska uszeregowano według alfabetu. Dla jasności przekazu wersalikami zapisano jeden $\mathrm{z}$ wielu lub jedyny wariant nazwiska.

\section{Analiza nazwisk}

ACHNICHT: formy słownikowe: Achtnich, Achtnig, Achtsnicht, Achtsnichts. przezwisko beztroskich ludzi (Duden, 2005, s. 80; Brechenmacher, 1957-1960, s. 7). Podstawą tego nazwiska jest nazwisko zdaniowe w języku średniowysoko-niemieckim: ,ich ahte sīn niht” „Nie martwię się o niego” (Duden, 2005, s. 80; Gottschald, 1954, s. 160). W badanej księdze chrztów wystąpiły dwie odmianki tego nazwiska:

- Achnicht 1606 E $462 \mathrm{k}^{2} .26$,

- Achnitz 1617 E 462 k. 66.

Jedenaście odmianek tego nazwiska, m. in.: Achtsnicht, Achnich występuje w spisie nazwisk z XVIII wieku w publikacji „Die Bevölkerung des Ermlands 1773. Die ältesten Prästationstabellen des Hochstifts“ (dalej BE) (Heling \& Poschmann, 1997, s. 35), natomiast w „Słowniku nazwisk współcześnie w Polsce używanych” (Rymut, 1992) z początku lat dziewięćdziesiątych $\mathrm{XX}$ wieku brak tego miana.

ALLEN, von: forma słownikowa: Allen: np. Aschen van Allen (XIV w.), chodzi tu o nazwę miejscowości w Wesfalii (Bahlow, 1976, s. 29). W księdze z Reszla to nazwisko wystąpiło jeden raz.

- Allen: V. Allen 1608 E 462 k. 34.

Takie miano nie jest zarejestrowane w spisie nazwisk z XVIII wieku (BE).

${ }^{2}$ K. to skrót od słowa karta. W Księdze Chrztów z Reszla numerowana jest co druga karta, jeśli chodzi o rewers numerowanej karty używa się dalej w tekście skrótu v. - verso, np. k. 10 v. (odwrotna strona karty nr 10). 
ALEX: od skróconej formy imienia Alexander (Duden, 2005, s. 86). W księdze z Reszla to nazwisko wystąpiło jeden raz.

- Alex. Martinus Alex Catharina uxor, Dorothea 1601 E 462 k. 12.

To miano figuruje także w spisie nazwisk z XVIII wieku (BE, s. 35).

ARENTH: z dolnoniemieckiej formy skróconej imienia Arnold (Duden, 2005, s. 94; Naumann, 1989, s. 58). W księdze z Reszla to nazwisko wystąpiło w kilku odmiankach:

- Arend: Arend 1616 E 462 k. 65,

- Arendt. Anna Pauli Arendt filia 1600 E 462 k. 10 v., Arendt 1604 E 462 k. 17, Arendt 1606 E 462 k. 25, Arendt 1606 E 462 k. 25 v., Arendt 1607 E 462 k. 26 v., Arendt 1610 E 462 k. 43 v., Arendt 1610 E 462 k. 45 v., Arendt 1613 E 462 k. 51, Arendt 1615 E 462 k. 61v., Arendt 1616 E 462 k. 65, Arendt 1617 E 462 k. 67 v., Arendt 1617 E 462 k. 68 v.,

- Arenth: Hedwigis u., Thobias, Paulus Arenth chirurgus 1579 E 462 k. 1. v., Paulus Arenth chyrurgus 1579 E 462 k. 3, Paulus Arenth chirurgus $1580 \mathrm{E} 462 \mathrm{k} .6 \mathrm{v}$.,

- Arent. Arent 1607 E 462 k. 29 v., Arent 1612 E 462 k. 50, Arent 1614 E 462 k. 56 (2x), Arent 1615 E 462 k. 60 v., Arent 1616 E 462 k. 64, Arent 1616 E 462 k. 64 v., Arent 1617 E 462 k. 68 v., Arent 1618 E 462 k. 69 v., Arent 1618 E 462 k. 71,

- Arndt. Arndt 1609 K. 39, Arndt 1609 E 462 k. 41v.

$\mathrm{W}$ ww. nazwisku nastąpiła wymiana $d \rightarrow d t \rightarrow t$ w wygłosie po $n$. Jej przyczyną jest to, że germańskie $d \mathrm{w}$ dużej części wysoko-niemieckiego obszaru zostało przesunięte $\mathrm{w}$ języku staro-wysoko-niemieckim do $t$, stąd taka zróżnicowana pisownia (Kunze \& Nübling, 2011, s. 345). Odnośnie do wymiany $d t \rightarrow t$ dodać należy, że podwojone konsonanty, w języku niemieckim częściowo relewantne, wskazując m.in. na iloczas poprzedzajacej samogłoski, w polszczyźnie nie znajdują zrozumienia i są często eliminowane (Lica, 2009 b, s. 188). Digraf th stosowano w wygłosie na oznaczenie bezdźwięcznej $t$ (Lasch, 1914, s. 163, Lica, 2009 a, s. 192).

Nazwisko to notowane jest w XVIII wieku (BE, s. 36) także w kilku innych odmiankach: Arnd, Arndt, Arnt oraz w słowniku K. Rymuta (1992 s. 40): Arendt. 673, Arent. 11, Arndt. 24.

\footnotetext{
${ }^{3}$ Liczby wskazują ilość nosicieli nazwiska w XX w. w województwie olsztyńskim (do 1998 roku). Po reformie 1.01.1999 województwo olsztyńskie znalazło się w całości w województwie warmińsko-mazurskim.
} 
ARTMAN: 1. Nazwisko odzawodowe chłopa, rolnika (Duden, 2005, s. 96), 2. Nazwisko od miejsca zamieszkania od średnio-wysoko-niemieckiej formy ort 'koniec': 'ktoś mieszkający na końcu' (Duden, 2005, s. 96). W księdze z Reszla to nazwisko wystąpiło w jednej formie:

- Artman: Joannes Artman 1604 E 462 k. 19, Petrus Artman 1604 E 462 k. 19.

Miano nie pojawiło się w XVIII-wiecznym spisie z Warmii.

ASMAN: formy słownikowe: Assmann, Aßmann: nazwisko derywowane sufiksem - mann od spieszczonej formy imienia Erasmus (Duden, 2005, s. 98). W badanej księdze nazwisko wystąpiło w trzech odmiankach:

- Asman: Georgius Asman pistor 1604 E 462 k. 16, Asman 1604 E 462 k. 18, Asman 1605 E 462 k. 20, Asman 1606 E 462 k. 26 (2x), Asman 1607 E 462 k. 30 v., Asman 1608 E 462 k. 33, Asman 1609 E 462 k. 40, Asman 1610 E 462 k. 42, Asman 1610 E 462 k. 43 v., Asman 1613 E 462 k. 52, Asman 1614 E 462 k. 56,

- Asmann: Asmann 1606 E 462 k. 26,

- Aßmann: A $\beta$ mann 1606 E 462 k. 24.

$\mathrm{W}$ tym mianie widoczna jest wymiana $s \rightarrow \beta$. Znak $\beta$ pojawił się w XIV wieku jako ligatura dwóch liter. Pierwotnie reprezentował on przede wszystkim bezdźwięczny, przedniojęzykowo-zębowy spirant powstały z germańskiego $t$ W wyniku przesuwki, który później zbiegł się z germańskim $s$. W wyniku tego pisownię $\beta$ stosowano także zamiast innych głosek $s$, zwłaszcza bezdźwięcznych. Dopiero od XVI wieku zaczęto czynić starania, aby uregulować zasady pisowni ss i $\beta$ (Kunze \& Nübling, 2011, s. 509).

Pojedyncze $n \mathrm{w}$ wygłosie może świadczyć o polonizacji nazwiska. Podwojone spółgłoski, relewantne $\mathrm{w}$ języku niemieckim", nie znajdują zastosowania w języku polskim i dlatego są często usuwane (Lica, 2009 a, s. 249).

Nazwisko Asman występuje w sześciu odmiankach w spisie z XVIII wieku (BE, s. 36).

ASMANS: forma derywowana paradygmatycznie (w dopełniaczu) od Asman. Asmans: Asmans 1608 E 462 k. 32 v. Mocny dopełniacz z formantem - $s$ pojawia się $\mathrm{w}$ patronimach (nazwiskach od imienia ojca) oraz $\mathrm{w}$ nazwiskach odzawodowych zakończonych na -er (por. Kunze \& Nübling, 2012, s. 15).

\footnotetext{
4 Niemcy używają podwojonych liter spółgłoskowych dla oznaczenia krótkości poprzedzających samogłosek (Smoczyński, 1965, s. 27).
} 
BAHDER: w słownikach nie figuruje takie nazwisko, są natomiast formy zbliżone:

Bader. nazwisko odzawodowe kogoś, kto prowadzi łaźnię (Duden, 2005, s. 102; por. Brechenmacher, 1957-1960, s. 58; Naumann, 1989, s. 58), Bahde: Bade: nazwisko powstałe z dolnoniemieckiej formy skróconej imion z cząstką bode (Duden, 2005, s. 102), możliwe też pochodzenie od przezwiska bate, pate 'chrzestny ojciec, chrześniak' (Naumann, 1989, s. 59), może od nazwy miejscowości Bauda (Naumann, 1989, s. 59). W badanej księdze nazwisko wystąpiło jeden raz:

- Bahder. Bahder 1605 E 462 k. 22.

W tym nazwisku może chodzić o wzdłużenie krótkiej samogłoski przez nieme $h(\varnothing \rightarrow$ h, jak np. Berend $\rightarrow$ Behrend (Duden, 2005, s. 119)).

W spisie z XVIII wieku (BE, s. 36) i w słowniku K. Rymuta (Rymut, 1992, s. 118) figuruje nazwisko Bader, w XX wieku miało ono 37 nosicieli.

BAHR: 1. Przezwisko lub nazwisko od nazwy domu od średnio-dolnoniemieckiego bare 'niedźwiedź' (Duden, 2005, s. 103), 2. rzadko przezwisko od średnio-wysoko-niemieckiego bar 'syn, wolny człowiek' (Duden, 2005, s. 103), 3. Łużyckie nazwisko od górnołużyckiego, dolnołużyckiego bar 'niedźwiedź', zapożyczenie z języka niemieckiego (Duden, 2005, s. 103). W badanej księdze nazwisko wystąpiło w trzech odmiankach:

- Baahr. Johannes Baahr Catharina uxor, Martinus 1603 E 462 k. 15,

- Bahr. Gregorius Bahr, \& Anna uxor, Iaacobus 1580 E 462 k. 7, Arkatius Bahr Catharina uxor eius, Susanna 1600 E 462 k. 8, Thomas Bahr Eufemia uxor, Martinus 1600 E 462 k. 10, Georgius Bahr [...]1603 E 462 k. 14 v., Matheus Gregorii Bahr 1603 E 462 k. 14 v., Ertmundis Johannes Bahr famula 1603 E 462 k. 14 v., Elizabeth Gregorii Bahr uxor 1603 E 462 k. 15 v., Bahr 1604 E 462 k. 18, Bahr 1605 E 462 k. 22 v., Bahr 1609 E 462 k. 41, Bahr 1611 E 462 k. 47 v., Bahr 1612 E 462 k. 50 v., Bahr 1613 E 462 k. 51 v., Bahr 1613 E 462 k. 52 v., Bahr 1615 E 462 k. 59 v.,

- Bar. Bar 1607 E 462 k. 27 (2x).

W nazwisku Baahr może chodzić o podwajanie samogłosek bez uzasadnienia. Przykład tego zjawiska podaje R. Zoder (1968 I, s. 132). Forma Bar jest spolonizowana.

Nazwisko Bahr jest zarejestrowane w spisie z XVIII wieku (BE, s. 36), ze słownika K. Rymuta (Rymut, 1992, s. 125) wynika, że w XX wieku miało 21 nosicieli. 
BARSCH: 1. Przezwisko odzawodowe funkcjonujące głównie w północnych Niemczech, od nazwy ryby 'okoń' (Duden, 2005, s. 109), 2. Może od łużyckiego derywatu od imienia Bartłomiej (Duden, 2005, s. 109). W badanej księdze nazwisko wystąpiło jeden raz:

- Barsch: Joannes Barsch 1609 k. 40.

Tego miana nie ujęto w spisie nazwisk z XVIII wieku.

BARTZ: 1. Nazwisko derywowane za pomocą sufiksu $-z$ od zdrobnienia imienia Bartholomäus 'Bartłomiej' (Duden, 2005, s. 111), 2. Od nazwy miejscowości Barz w Meklemburgii-Pomorzu Przednim (Duden, 2005, s. 111). W badanej księdze nazwisko wystąpiło jeden raz:

- Bartz. Michael Bartz ex Torninen 1600 E 462 k. 9, Bartholomaeus Bartz [...]1604 E 462 k. 17.

Miano Bartz ujęto w spisie nazwisk z XVIII wieku (BE, s. 37).

BARTZEN: derywat paradygmatyczny w dopełniaczu od Bartz. Bartzen 1608 E 462 k. 34 v., Bartzen 1609 K. 40. Słaby dopełniacz z formantem -en występuje:

- w nazwiskach od imion zakończonych na samogłoskę, np. Otto $\rightarrow$ Otten (dopełniacz);

- w nazwiskach od imion zakończonych na $-s,-z$, np. Franz $\rightarrow$ Franzen (Kunze \& Nübling, 2012, s. 45);

- w nazwiskach odzawodowych i odprzezwiskowych, np. Graf $\rightarrow$ Grafen (Kunze \& Nübling, 2012, s. 61).

BECHER: nazwisko odzawodowe osoby uzyskującej smołę drzewną lub tokarza, który wytwarzał puchary i dzbanki z drewna (Duden, 2005, s. 115). W badanej księdze nazwisko wystąpiło jeden raz:

Becher. Joseph Becher ephipparius 1600 E 462 k. 10 v.

W spisie nazwisk z XVIII wieku brak tego miana.

BECKER: nazwisko odzawodowe od średnio-wysoko-niemieckiego, średniodolno-niemieckiego becker 'piekarz' (Naumann, 1989, s. 63; Bahlow, 1976, s. 52). Miano Becker nie ma więcej odmianek w Księdze Chrztów z Reszla:

- Becker. Joseph Becker ephipparius 1601 E 462 k. 11v., Becker 1605 E 462 k. 21, Becker [...] 1607 E 462 k. 28 v., Becker 1607 E 462 k. 30, Becker 1608 E 462 k. 33 v. 
Miano Becker znajduje się w spisie nazwisk z XVIII wieku (BE, s. 38), wg K. Rymuta (Rymut 1992, s. 223) nazwisko to nosiło pod koniec XX wieku 10 osób w województwie olsztyńskim.

BECKERS: nazwisko derywowane paradygmatycznie, w dopełniaczu od Becker.

Beckers. Beckers 1603 k. 13, Beckers 1607 E 462 k. 31, Beckers 1608 E 462 k. 36, Beckers 1609 E 462 k. 38 v., Beckers 1609 E 462 k. 39, Beckers 1609 K. 40, Beckers 1609 K. 41v.

BEHM: formy słownikowe: Böhm, Behm: 1. Nazwisko od miejsca pochodzenia on nazwy kraju Czechy (Duden, 2005, s. 144), 2. Przezwisko osoby, która miała jakieś związki (np. handlowe) z Czechami (Duden, 2005, s. 144). W badanym dokumencie nazwa wystąpiła w dwóch odmiankach:

- Behm: Behm 1607 E 462 k. 27,

- Böhm: Böhm 1607 E 462 k. 29, Böhm 1608 E 462 k. 34.

Obecność dwóch powyższych form wynika $\mathrm{z}$ delabializacji, procesu fonetycznego polegającego na zatracie przez głoskę artykulacji wargowej (Polański, 2003, s. 328). Przykłady zróżnicowania w średnio-wysokoniemieckiej pisowni $\ddot{o}$, oe $\rightarrow e$ podają K. Kunze i D. Nübling (2009, s. 135).

Nazwiska Behm i Boehm figurują w spisie nazwisk z XVIII wieku (BE, s. 38).

BEHMWALDT/BEHNWALDT: słowniki onomastyczne nie rejestrują tego miana, ale istnieje nazwa pasma górskiego na pograniczu Czech, Niemiec i Austrii Böhmerwald, pol. Szumawa. Nazwisko to pojawiło się raz w badanym materiale:

- Behmwaldt/Behnwaldt. Michael Behmwaldt/Behnwaldt Catharina uxor, Leonarius 1600 E 462 k. 10.

To miano nie figuruje $\mathrm{w}$ spisie z XVIII wieku.

BEILINGERS: słowniki onomastyczne nie rejestrują tego miana, ale istnieje miejscowość i gmina Beilingen położona w Niemczech, w kraju związkowym Nadrenia-Palatynat. W badanym materiale nazwisko wystąpiło raz:

- Beilingers. Beilingers 1601 K. 12.

Nazwisko utworzone za pomocą sufiksu -er, wskazującego na mieszkańca miejscowości, występuje dodatkowo w mocnym dopełniaczu z formantem $-s$. Brak tego nazwiska w XVIII-wiecznym spisie. 
BENFELT: nazwisko od nazwy miejscowości (Brechenmacher, 1957-1960, s. 99), Bendfeld - gmina w Niemczech, w kraju związkowym SzlezwikHolsztyn. W badanym materiale nazwisko wystąpiło raz:

- Benfelt. Benfelt 1609 K. 40 v.

$-t \mathrm{w}$ wygłosie zamiast $-d$ wynika prawdopodobnie $\mathrm{z}$ polonizacji. Być może $\mathrm{w}$ celu uproszczenia grupy spółgłoskowej zanikło - $d$ w śródgłosie.

Do XVIII wieku przetrwała odmianka Benfeld.

BERENDT: formy słownikowe: Berend, Berendt. nazwisko powstało $\mathrm{z}$ dolnoniemieckiej formy skróconej imienia Bernhard (Duden, 2005, s. 124). W badanym rękopisie miano wystąpiło w czterech odmiankach:

- Berendt. Georgius Berendt et Ursula uxor coloni 1579 E 462 k. 2 v., Elisabeth Georgii Berendt filia ex [...]1600 E 462 k. 8 v., Berendt 1600 K. 10, Berendt 1600 K. 10 v., Clemens Berendt 1603 E 462 k. 15, Berendt 1605 E 462 k. 21 v., Berendt 1605 E 462 k. 22 v., Berendt 1612 E 462 k. 48 v., Berendt 1617 E 462 k. 67 v.,

- Berent. Berent 1607 E 462 k. 27 v., Berent 1607 E 462 k. 28 v., Berent 1608 E 462 k. 32 v., Berent 1608 E 462 k. 35, Berent 1609 E 462 k. 38, Berent 1610 E 462 k. 42 (2x), Berent 1610 E 462 k. 42, Berent 1610 E 462 k. 42 v., Berent 1610 E 462 k. 44 v., Berent 1610 E 462 k. 45 (2x), Berent 1611 E 462 k. 47, Berent 1611 E 462 k. 47, Berent 1612 E 462 k. 50, Berent 1614 E 462 k. 55 v., Berent 1614 E 462 k. 56, Berent 1616 E 462 k. 64, Berent 1617 E 462 k. 66, Berent 1618 E 462 k. 71 v.

- Berentt. Berentt 1606 E 462 k. 23 v.,

- Bernt. Bernt 1609 E 462 k. 41v.

W analizowanym rękopisie najbardziej frekwentywną odmianką jest Berent. $\mathrm{Z}$ podwajaniem spółgłosek bez uzasadnienia mamy do czynienia w przypadku odmianki Berentt. Przykłady tego zjawiska prezentuje m.in. R. Zoder (1968 I, s. 132). Synkopa -e jest widoczna w odmiance Bernt $\leftarrow$ Berent, por. zjawisko synkopy w nazwiskach na Warmii w XVIII wieku Hildebrand $\rightarrow$ Hilbrand, Hilbrant (Guz, 2018, s. 108).

Nazwisko Berendt figuruje $\mathrm{w}$ spisie nazwisk z XVIII wieku w siedmiu odmiankach: Behrend, Behrendt, Behrent, Berend, Berendt, Berent, Berenth (BE, s. 38, 39). W XX wieku też było dość popularne, wg K. Rymuta (Rymut 1992, s. 229) nazwisko Behrendt nosiły 53 osoby, a Berendt 35.

BERENTS: nazwisko derywowane paradygmatycznie w mocnym dopełniaczu za pomocą formantu $-s$ od Berent. 
Berents: Berents 1608 E 462 k. 32, Berents 1608 E 462 k. 34 v., Berents 1608 E 462 k. 36 v., Berents 1612 E 462 k. 48 v., Berents 1617 E 462 k. 68 v.

BERNTS: nazwisko derywowane paradygmatycznie w mocnym dopełniaczu za pomocą formantu - $s$ od Bernt.

Bernts: Bernts 1612 E 462 k. 50.

BERG, vom: forma słownikowa: Berg. 1. n. od m. zam. 'zamieszkały na górze' (Duden, 2005, s. 124; Brechenmacher, 1957-1960, s. 102), 2. n. od m. poch. od n. m. Berg, Berga, Berge, Bergen (Duden, 2005, s. 124). Miano z przyimkiem von pojawia się raz $\mathrm{w}$ rękopisie:

- Berg, vom: vom Berg 1613 E 462 k. 51.

Nazwisko w dwóch odmiankach Berg i Bergk ujęte jest w spisie z XVIII w. (BE, s. 39), w słowniku K. Rymuta (Rymut, 1992, s. 345) znajduje się informacja, że nazwisko to nosiło 48 osób.

BETHER: nazwisko derywowane za pomocą sufiksu -er od Beth(ge): 1 . Nazwisko powstałe $\mathrm{z}$ dolnoniemieckiego spieszczenia imienia Bertholt lub Bertram (Duden, 2005, s. 129), 2. Może nazwisko matronimiczne od imienia matki Beteke, spieszczenia imienia Elisabeth (Duden, 2005, s. 129). Miano to występuje w XVI- i XVII- wiecznym dokumencie w dwóch odmiankach:

- Bether. Bether 1600 K. 10 v.,

- Betger. Betger 1607 K. 28.

Powyższe miana nie pojawiły się w spisie z XVIII wieku.

BETGERS: derywat paradygmatyczny w mocnym dopełniaczu od Betger.

Betgers: Betgers 1607 K. 28 v.

BETTMAN: forma słownikowa: Bethmann: dolnoniemieckie spieszczenie imienia Bertram (Brechenmacher, 1957-1960, s. 114). W rękopisie z Reszla znajdują się dwie odmianki:

- Betman: Betman 1618 E 462 k. 71v.,

- Bettman: Bettman 1615 E 462 k. 62.

Forma Betman jest prawdopodobnie spolonizowana. Żadna $\mathrm{z}$ odmianek nie figuruje w spisie z XVIII wieku.

BIERMAN: forma słownikowa Biermann: n. odzawodowe handlarza piwem z sufiksem -mann (Duden, 2005, s. 133; Brechenmacher, 1957-1960, s. 138; Bahlow, 1976, s. 61). W rękopisie miano pojawia się w jednej odmiance: 
Bierman: Nicolaus Bierman filius sculteti 1580 E 462 k. 6 v., Bierman 1605 E 462 k. 22 v.

Pierwotne podwójne wygłosowe $n$ zostało zredukowane do pojedynczego, co wskazuje na polonizację.

Odmianki Biermann i Bierman występują też w spisie z XVIII wieku (BE, s. 40). Wg słownika K. Rymuta (Rymut, 1992, s. 330) odmianka Bierman miała 6 nosicieli, Biermann: 30, Birman: 10.

BÜTNER: forma słownikowa: Büttner. nazwisko odzawodowe bednarza od średnio-wysoko-niemieckiego büt [t]e 'beczka na wino' (Duden, 2005, s. 168; Gottschald, 1954, s. 195; Naumann, 1989, s. 82). W badanym dokumencie pojawiają się dwie odmianki:

- Bütner. Bartholomeus Bütner Anna uxor eius, Ursula 1600 E 462 k. 9 v.

- Bitner. Bitner 1609 E 462 k. 37 v., Bitner 1614 E 462 k. 55 v., Bitner 1616 E 462 k. 64 v.

Bittner to forma $\mathrm{z}$ utratą zaokrąglenia samogłosek od Büttner. Podwójne $t$ w śródgłosie zostało zredukowane do pojedynczej spółgłoski pewnie w ramach polonizacji.

Nazwiska Büttner i Bittner występują w spisie z XVIII wieku, zaś wg K. Rymuta (Rymut 1992, s. 342) nazwisko Bittner nosiły 3 osoby. Wariant Büttner $\mathrm{w}$ XX wieku już się nie pojawia. Może trochę dziwić, że w XVII wieku było to miano spolonizowane, ale pamiętać należy, że mógł je zapisać polski ksiądz, zaś spis nazwisk w XVIII wieku wkrótce po I rozbiorze Polski sporządzili Niemcy.

BLADAU: nazwisko od nazwy miejscowości Bladau w Prusach (Wald, 1979, s. 238). W badanej księdze pojawia sie jeden raz:

- Bladau: Bladau 1608 E 462 k. 32.

Miano to zanotowano w spisie z XVIII wieku w odmiankach: Bladau, Blodau, Bloudau oraz Bludau (BE, s. 41).

BLANCK: 1. przezwisko od średnio-wysoko-niemieckiego blanc 'biały, błyszczący, piękny' w odniesieniu do koloru skóry lub włosów lub pięknej sylwetki pierwszego nosiciela nazwiska (Duden, 2005, s. 137; Brechenmacher, 1957-1960, s. 151; Gottschald, 1954, s. 196; Naumann, 1989, s. 69), 2. rzadziej nazwisko od miejsca zamieszkania od średnio-wysoko-niemieckiego planke 
'płot z desek' (Naumann, 1989, s. 69). Nazwisko pojawiło się raz w badanej księdze:

Blanck. Blanck 1611 E 462 k. 46 v.

Dwie odmianki miana Blanck i Blank zawiera spis z XVIII wieku (BE, s. 41), wg słownika K. Rymuta (Rymut 1992, s. 349) formę spolonizowaną Blank nosiło 49 osób na terenie województwa olsztyńskiego w latach 90-tych XX wieku.

BLUMENSTEIN: 1. Nazwisko od miejsca zamieszkania od nazwy niwy, pola (Duden, 2005, s. 141), 2. Nazwisko od nazwy miejscowości Blumenstein w Prusach Wschodnich i Szwajcarii (Duden, 2005, s. 141).

W badanym materiale brak innych odmianek:

- Blumenstein: Valentinus Blumenstein colonus 1579 E 462 k. 3 v.

Nazwiska brak w spisie z XVIII wieku.

BOGENHEISER: forma słownikowa: Bogenhauser. nazwisko derywowane sufiksem -er od nazwy miesjcowości Bogenhausen w Bawarii (Brechenmacher, 1957-1960, s. 172). W badanej księdze chrztów pojawiły się trzy odmianki tego miana:

- Bogenheiser. Bogenheiser 1601 K. 11 v., Bogenheiser 1604 E 462 k. 17 v., Bogenheiser 1610 E 462 k. 43 v., Bogenheiser 1610 E 462 k. 45 v., Bogenheiser 1611 E 462 k. 47 v., Bogenheiser 1612 E 462 k. 49, Bogenheiser 1612 E 462 k. 50, Bogenheiser 1614 E 462 k. 56, Bogenheiser 1614 E 462 k. 57, Bogenheiser 1616 E 462 k. 64 v,

- Bogenheißer. Bogenheißer 1606 E 462 k. 26, Bogenheißer 1612 E 462 k. 50 v.,

- Bogenheyser. Bogenheyser 1604 K. 16 v., Bogenheyser 1605 E 462 k. $20 \mathrm{v}$.

Najczęstszą odmianką w badanym rękopisie jest forma Bogenheiser. Wymiana au $\mathrm{w}$ Bogenhauser na ei $\mathrm{w}$ Bogenheiser wynika stąd, że sufiks -er wywołał $\mathrm{w}$ wielu regionach przegłos, który zapisywano jako äu lub eu, a nawet dochodziło do delabializacji do ei (Kunze \& Nübling, 2009, s. 497). W tym mianie widoczna jest też wymiana $s \rightarrow \mathcal{B}$, o której napisano więcej przy omawianiu nazwy osobowej Asman. Zmiana ei $\rightarrow$ ey wynika $\mathrm{z}$ różnych sposobów zapisu średnio-wysoko- i średnio-dolno-niemieckiego ei w średniowieczu (Kunze \& Nübling, 2009, s. 465).

Nazwiska brak w spisie nazwisk z XVIII wieku.

BOGENHEISERS: derywat paradygmatyczny $\mathrm{w}$ mocnym dopełniaczu od Bogenheiser. Bogenheisers. Bogenheisers 1601 K. 12. 
BOHMHEUREN: forma słownikowa: Bohmheuer, Baumhauer. nazwisko odzawodowe drwala (Brechenmacher, 1957-1960, s. 174) $\mathrm{z}$ formantem paradygmatycznym -en, co wskazuje na słaby dopełniacz. W rękopisie ta nazwa osobowa nie ma odmianek:

- Bohmheuren: Bohmheuren 1608 E 462 k. 35 v.

Tego miana brak w rejestrze z XVIII wieku.

\section{Wnioski}

W artykule opisano 33 nazwiska. Wśród nich 10 to nazwiska wielomotywacyjne, większość stanowią nazwiska o jednej motywacji. Nazwiska jednomotywacyjne pochodzą od nazw miejscowości, np. Allen, od nazw zawodów, np. Biermann oraz imion, np. Alex. Wystąpiło też nazwisko zdaniowe Achnicht. W całym badanym zbiorze częstsze są nazwiska niederywowane. Nazwiska derywowane słowotwórczo są trzy, np. Asman, zaś paradygmatycznie dziesięć, np. Bartzen. Odmianki (warianty) posiada 10 nazwisk. Najwięcej odmianek mają nazwiska Arend (4) i Berndt (5). Przyczynami występowania odmianek badanych nazwisk są: synkopa - $e$; wymiana $d \rightarrow d t \rightarrow t, t \rightarrow t h, s \rightarrow B$, polonizacja nazwisk, wzdłużenie samogłoski przez nieme $h$, podwajanie samogłosek i spółgłosek bez uzasadnienia, delabializacja, uproszczenie grupy spółgłoskowej, wymiana dyftongów. Do XVIII wieku nie przetrwało 10 nazwisk, m. in.: Artman, Barsch, Becher, Behmwaldt. W XX wieku pojawiło się dziewięć z badanych nazwisk, m. in.: Bader, Bahr, Behrendt, Blank.

$$
\begin{aligned}
& \text { Skróty } \\
& \text { k. - karta } \\
& \text { pol. - polski } \\
& \text { u. - uxor (żona) } \\
& \text { v. - verso (na odwrocie karty) }
\end{aligned}
$$

\section{BIBLIOGRAFIA}

Bahlow, H. (1976). Deutsches Namenlexikon. Familien- und Vornamen nach Ursprung und Sinn erklärt. Baden-Baden: Suhrkamp.

BE = Heling, R. \& Poschmann, B. (red.) (1997). Die Bevölkerung des Ermlands 1773. Die ältesten Prästationstabellen des Hochstifts. Band 3 - Register. Zeitschrift für die Geschichte und Alterstumkunde Ermlands, 13/3, 7-34 (Spis miejscowości), s. 35-138 (Spis osób). 
Brechenmacher, J. K. (1957-1960). Etymologisches Wörterbuch der Deutschen Familiennamen. $A$-J. Limburg a.d. Lahn: C. A. Starke Verlag.

Cieślikowa, A. (2008). Grafia i fonetyka w nazwiskach Polaków. W: J. Trempała i in. (Red.), Studia linguistica in honorem Edvardi Breza (ss. 30-36). Bydgoszcz: Wydawnictwo Uniwersytetu Kazimierza Wielkiego.

Duden. Familiennamen. Herkunft und Bedeutung. Bearbeitet von Rosa und Volker Kohlheim (2005). Mannheim/ Leipzig/ Wien/ Zürich: Dudenverlag.

Gottschald, M. (1954). Deutsche Namenkunde. Unsere Familiennamen nach ihrer Entstehung und Bedeutung. Berlin: de Gruyter.

Guz, M. (2018). Nazwiska niemieckie na Warmii u schyłku XVIII wieku. Olsztyn: Wydawnictwo Uniwersytetu Warmińsko-Mazurskiego,

Hartig, J. (1996). Morhologie und Wortbildung der Familiennamen: Germanisch. W: E. Eichler i in. (Red.), Namenforschung. Ein internationales Handbuch zur Onomastik. (ss. 12591262). Berlin, New York: Walter de Gruyter.

Kunze, K. \& Nübling, D. (Red.) (2009). Deutscher Familiennamenatlas. Tom 1: Graphematik/ Phonologie der Familiennamen I: Vokalismus. Berlin/ New York: De Gruyter.

Kunze, K. \& Nübling, D. (Red.) (2011). Deutscher Familiennamenatlas. Tom 2: Graphematik/ Phonologie der Familiennamen II: Konsonantismus. Berlin/ New York: De Gruyter.

Kunze, K. \& Nübling, D. (Red.) (2012). Deutscher Familiennamenatlas. Tom 3: Morphologie der Familiennamen. Berlin, New York: De Gruyter.

Lasch, A. (1914). Mittelniederdeutsche Grammatik. Halle: Niemeyer.

Lica, Z. (2009 a). Sposoby adaptacji nazwisk pomorskich genetycznie niemieckich w polszczyźnie. Gdańsk: Wydawnictwo Uniwersytetu Gdańskiego.

Lica, Z. (2009 b). Polskie adaptacje ortograficzne nazwisk pomorskich genetycznie niemieckich. W: J. Maćkiewicz, E. Rogowska-Cybulska (Red.): Polonistyczne drobiazgi językozawcze (ss. 184-191). Gdańsk: Wydawnictwo Uniwersytetu Gdanskiego.

Naumann, H. (1989). Familiennamenbuch. Leipzig: VEB Bibliographisches Institut.

Polański, E. (Red.) (2003). Encyklopedia językoznawstwa ogólnego. Wrocław, Warszawa, Kraków: Zakład Narodowy imienia Ossolińskich. Wydawnictwo.

Rymut, K. (1992). Słownik nazwisk współcześnie w Polsce używanych. T. 1 A-B. Kraków: PAN. IJP

Siatkowski, J. (1967). Interferencje językowe na Warmii i Mazurach. Studia z filologii polskiej i słowiańskiej, 7, 103-115.

Smoczyński, P. (1965). Trudności Niemców z wymową polską oraz związane z tym inne lingwistyczne problemy. Język Polski, XLV 1, 22-31.

Tolksdorf, U. (1991). Ermländische Protokolle. Alltagserzählungen in Mundart. Marburg: Elwert.

Wald, S. G. (1979). Topographische Übersicht des Verwaltungsbezirks der Königlichen Preußischen Regierung zu Königsberg in Preußen. Hamburg: Verein für Familienforschung in Ost- $\mathrm{u}$. Westpreußen.

Zoder, R. (1968). Familiennamen in Ostfalen, I-II. Hildesheim: Georg Olms Verlagsbuchhandlung.

Żebrowska, E. (1998). Dialekty niemieckie na terenie Warmii. Studia Warmińskie, XXXV, 449-459. 